Abstract

Not only physical presences, but also histories and memories of the cities transform. The changes in the built environments result in the erasure of past records from urban space as well as from the minds of urban dwellers. Photographs and movies record the past and document the life and culture in the built environment. Movie theaters are important as they are the sites of meanings and memories of the past. First movie theaters were built after cinema was embraced by urban dwellers as a cultural activity and a realm of socialization. In order to be accessible by citizens, movie theaters were positioned at the centers of the cities as new social and public spaces. In Turkey, cinema appeared as an institution after the republic was established, spread in 1940s, and became a lifestyle and a means of socialization in 1960s. Pioneering steps of the cinema culture took place in Istanbul and soon spread primarily in big cities such as Ankara, Adana, Izmir, and Eskisehir. Eskisehir also met cinema culture in the republican period. As cinema became a popular means of socialization, the number of movie theaters including open air theaters raised up to 25 in the most vivid period. The advent and expansion of TV in 1970s and video in 1980s, however, undermined the cinema culture. In the later years, the cinema culture which existed in many independent movie theaters spread in various
Keywords: Cinema culture, movie theaters, movie theaters in Eskisehir.

*Assoc. Prof. Dr. Eskisehir Technical University, Department of Architecture Eskişehir, Turkey, E-mail: bustun2012@gmail.com Orcid ID: http://orcid.org/0000-0002-37906493 
parts of the city transformed into the smaller multi-movie-theaters in sterile spaces, i.e. shopping malls, as a part of shopping and dining culture. The movie theaters were not able to resist capitalism, and closed down one by one, and were erased from the urban space as well as from the memories of the citizens. This research aims at exploring and documenting the transformation of Eskisehir's independent movie theater buildings, which were considered as spaces of socialization for many years in the modernization process of the republican period.

\section{INTRODUCTION AND SCOPE OF THE STUDY}

Watching movies, discussing about movies, are talking on cinema are all acts of socialization process, and according to Jarvie (1970), this is what makes cinema a social institution, such as family, religion and school (Jarvie, I. C., 1970, as cited in Erkılıç, H., 2009: 144). Hauser considers cinema as a democratic art, since it does not belong exclusively to a class or to a cultural circle. "Unlike plastic arts such as painting and sculpture, and unlike high culture products such as classical music, cinema address all layers of the society and bring them together in the movie theaters for the duration of the screening." This is why cinema was considered to have a structure that resolve class differences, and to be the most popular field of art (Hauser, A., 1984: 420, as cited in Erkılıç, H., 2009: 144).

Movie theaters are an extension of public urban spaces; therefore, they are more than places to watch movies only: They are spaces that constitute street culture and urban identity. Movies screened in a city, and the social characteristics of the audience should be studied as indications of urban development levels (Kirel, 2005: 191). In this context, this research focuses on the development of cinema culture in Turkey, the importance of performance arts (cinema, theater, etc.) in the socio-cultural life of Eskisehir, and gradual disappearance of independent movie theaters in the city.

\section{DEVELOPMENT OF CINEMA CULTURE IN TURKEY}

Cinema began with the first movie screening in Le Grand Café, Paris, in 1825 by Louis Lumiere (Ulutak, N., 1988: 1). Soon after its emergence, cinema was introduced in Turkey too. Sigmund Weinberg, who was a follower of what happened in Europe, and who had connections with the company Pathe, screened the first movie to the public in Sponeck Brasserie in Galatasaray, Istanbul on December $12^{\text {th }}, 1896$. Weinberg continued the screenings in Fevziye Coffee House to the public, and to special groups (Akçura, G., 2004: 175-177).

The number of movie theaters in Turkey was so limited until 1920. There were ten movie theaters, most of them being in Istanbul, and a few in Izmir. After 1923, especially between 1924 
and 1927, many movie theaters were built (Erkılıç, E., Kebikeç, 2009: 92).

The first movies were silent. The addition of sound was a much later technical improvement. As in all over the world, in the silent movie theaters in the Ottoman Empire, music was played live to attract people, to accompany the movie, and to enjoy the audience during the entractes. Depending on the sizes and characteristics of the movie theaters, a group of musicians used to play during entire screening. The groups would include a violin and a piano, and might well expand to an orchestra of ten or twelve. The bands used to prepare and rehearse what they would play in order to be synchronous with the moving images, and they watched the movies before they were screened to the public (Akçura, G., 2004: 189-191).

The first experiments in sound in movies during the silent movie period were performed with gramophones. On September $25^{\text {th }}$, 1929, in Opera Movie Theater in Beyoglu, Istanbul, the first sound film "Women Join the Army" was screened (Akçura, G., 2004: 196). Theater players dominated Turkish cinema until 1939, and their influence continued until 1950s. From 1950 on, cinema started to become a profession, with its own professionals. Experiments once being phantasies in the beginnings of cinematic art soon became business sector. Cinema went through crises in economic and political depression periods, but it sought its way out by innovations. As movie theaters have not only been the places of amusement, or cultural institutions; but also the reflections of social problems, they experiences many crises. Property owners of movie theaters had to direct their investments towards more fruitful solutions in time; and movie theaters became office buildings and residences (Bodur, F., 1990).

Open air movie theaters also appeared at the end of the $19^{\text {th }}$ century as soon as cinema was introduced in Turkey. The easiest way to build a cinema theater was to enclose a vacant lot with board fences in the places with appropriate climate conditions. About the garden movie theaters, Akçura claims the following: "Cinema manager of the early period soon discovered that. It is almost impossible to make an entire list of old open air movie theaters, since they were neither registered in city guides, nor in insurance maps. We cannot find much in memoires, either. Most of the old movie theaters did not even have names. They are generically called garden cinemas" (Akçura, G., 2004: 201). Especially in the months of Ramadan, many mobile movie theaters were built in vacant lots in various spots in cities, as well as in towns and villages of Anatolia as sole public entertainment means. Today, these nostalgic screenings are still held in many places. 


\section{SOCIO-CULTURAL LIFE IN ESKISEHIR / BEGINNING OF CINEMA AND THEATER IN ESKISEHIR}

Various important factors contribute to the socio-cultural life in Eskisehir. An essential one is the fact that groups of immigrants in various periods settled in the city and they shared their knowledge and experience with the local people. After the war between Ottomans and Russians in 1877-1878, many Rumelian immigrants settled in Eskisehir, and the city had a complex character with the variety of population, language, religion, race and culture. These communities with their distinct cultural traditions had intense cultural interactions with the local population called "manav". Immigrants were also the source of early improvements in agriculture and industry in Eskisehir (Kırll, E., 2001: 262-263).

Another important step in the development of the city is the construction of Anatolian railways. Three hundred workers and engineers from France, Italy and Switzerland lived in the city with their families for a long time. The documents show that 150 European families were living in Eskisehir in 1894. Railway employees were the examples of a new lifestyle for Anatolia, with their clothes, languages, schools, restaurants, hotels, clubs, and other social structures. Anatolia railways was put into service in 1892, and it made Eskisehir a vivid and developed city in its economy and daily life compared to other Anatolian cities, especially during the years of the First World War (Efe, Ayla, 1998: 97-98). Priests of Saint Augustine de I'Assomption settled in Eskisehir in 1891 and established a school to educate the children of European workers and engineers. 60-80 Catholic, Protestant, Orthodox, Gregorian, Jew and Muslim students learned French, Armenian, Turkish, mathematics and music in this school. Priests and sisters provided public health services (Sarıöz, P., 1997: 90). Documents show that the population of Eskisehir in 1893 was 67000,19000 of which were non-Muslim. Cucinet claims that there were 11 mosques, 6 prayer rooms, a Greek church, an Armenian church, and a Catholic chapel (Atuk, A., 2002: 114) (Figure 1).

Figure 1. Students and tutors in front of Saint Croix French College; from Pierre de Gigord's collection. Goksu Bridge, Armenian school and club at the beginning of the century; from Pierre de Gigord's collection (Sarıöz, P., 1997: 90).

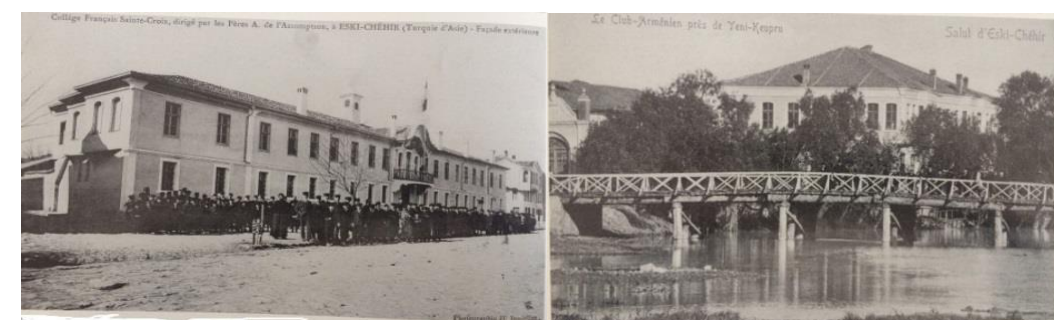

According to written sources, heater in its western sense appeared for the first time in Eskisehir in 1912. The Armenian 
Club established a theater in 1912, managed by Salim Bey, and it staged the works of Turkish writers. This theater was the origin of theater and cinema culture of the city with its multicultural structure (Baraz,T.,1988: 6).

In this period, many theater companies on tour staged their plays in Eskisehir, and many local theater activities were also held. Besides these, theatrical village plays continued to be a part of the cultural life in the city. Traditional Puppet Theater was also important for Eskisehir (Elmalığlu, E., 2006: 11).

The first quarter of the 20th century witnessed a vivid entertainment life in Eskisehir. The city was the stage for many cultural activities which cannot even be imagined today, and opera and ballet performances attracted many audiences (Atuk, A., 2002: 118).

Community Centers were established in 1932, and attached a great importance to theater. Eskisehir Community Center had a huge impact on the cultural development of the city, and Eskisehir Community Center Theater Group was a natural component in this process. The group performed many plays from 1933 to 1945. In 1933, Darülbedayi staged a play in Esksehir in its Anatolia tour. In 1934, many plays were performed in Asri (Modern) Movie Theater.

In late 1930s, there were many open air and garden theaters in Eskisehir, and in 1939, there were two plays a night, on five days a week. Theater critiques were published in a local newspaper, Kocatepe. Istanbul Municipal Theaters used to perform in Asri Movie Theater once a week, and in 1949 they started performing in Yeni (New) Movie Theater (note 1) (Elmalığlu, E., 2006: 1314-15). In this period, the number of movie theaters in the city center was five, most of which were garden movie theaters (Figure 2).

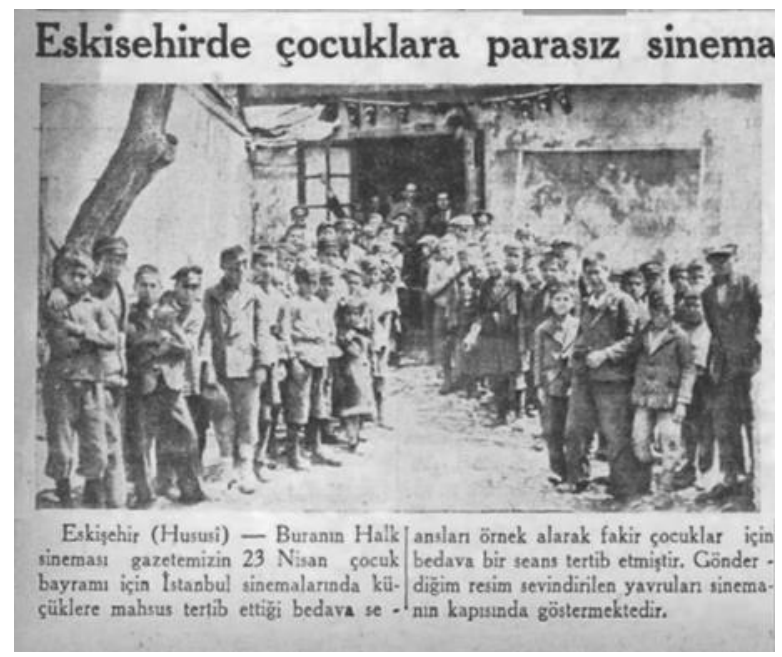

Figure 2. A newspaper report on May 2nd, 1937 (From Y. Yastıkçı's archive) Free screenings for children in Eskisehir 
Eskisehir (Special) - Local community movie theater takes what some movie theaters in Istanbul did for April 23rd National Sovereignty and Children's Day, and organizes free screenings for poor children. The picture shows the happy children at the gate of the theater.

After the Community Center in Eskisehir was closed, the theater could not find any other place as a stage. The problem was solved by Osman Bozok, the manager of Sugar Factory, who had a theater and concert hall built in the factory campus. This hall served Eskisehir's need for many years. After it was built, Istanbul Municipal Theaters and Ankara State Theater performed there. Eskisehir Atatürk High School's Thetaer Group also staged their plays there two nights a week; and the great interest Eskisehir audience showed made it necessary to develop an entrance fee system. After the establishment of a radio by the group, radio plays were started to be broadcasted (Elmalığlu, E., 2006: 18).

Further contribution to the socio-cultural development of the city came from the industrial campuses in the city, namely, State Railways and Sugar Factory campuses. State Railways Social Center was opened by İsmet İnönü in 1946. It was not only a venue for artistic and cultural activities, but also a realm where modern way of life was introduced to the public. It had two indoor halls and a garden where families and groups could gather in all seasons. Bands and jazz groups started performing in Ankara and in other cities from 1946 on, and aimed at spreading modern polyphonic music culture. An arts and sports magazine, which included actual news and technical information, started to be published in 1946, and filled the gap in the realm of publishing in the region. The Social Center served the urban public, and its sports halls, movie theater, guesthouse, educational units, cafeteria and library made it a center of attraction in Eskisehir. As this lifestyle was promoted in the media, the employees of this institutions were considered to be in a high status (Yatağan, N., 2013: 160). The first established theater was started by the students of the academia in 1960s, however it was closed due to financial reasons in a few years. Many theater groups performed in the city during 1970s and 1980s, and finally in 1986, the Department of Theater in the State Conservatory, Anadolu University was established, and the city had its first educational center for theater (Elmalıoğlu, E., 2006: 172-175). Cinema festivals organized annually in Anadolu University attract the attention of not only the students but also of the citizens of Eskisehir.

Throughout the modernization process of the republican period, public institutions shared their social facilities with the entire city, 
and this had a great impact on the development of the sociocultural life. Other vivid socio-cultural facilities in the city center were independent movie theaters and garden theaters around the river Porsuk.

\section{Garden Theaters in Eskisehir (Summer Theaters)}

The first movie screenings in Eskisehir date back to 1926-1928. The garden creenings started with Cemil of Erzincan. With his mobile projector and silver screen, he screened two-three movies together in tea gardens in the evenings (Bodur, F., 1990: 203-221, Arda, E., 2005: 11-12).

Park Movie Theater (1926-1945) and Ethem Garden Theater were the first summer theaters. İbrahim Kemal built a garden theater opposite Sakarya Police Station in 1920-1930, and screened short silent films. Hasan Tozman opened Yeni Bahçe (New Garden) Movie Theater and Tozman Garden Theater on Porsuk Boulevard in 1939. (note 2). İbrahim Çanakçı founded Asri Bahçe (Modern Garden), Küçük Atlas (The Little Atlas) and Büyük Atlas (The Grand Atlas) movie theaters on Porsuk Boulevard in 1952-1953. In 1950s, Ethem Berksoy and Muharrem Rıfkı Gösteren screened movies in the tea garden where Kılıçoğlu Movie Theater used to be until recently. In 1953, İbrahim Çanakçı transformed his summer theater to a building with a capacity of 300 audiences. After this building was torn down in 1958, Kılıçoğlu Movie Theater was built in 1961 in the same spot. Çiçek Bahçe (1942), Renk Bahçe (1973-1978), Emek Bahçe (1975), Dilek Bahçe and Bahar Bahçe were the other garden cinemas on Porsuk Boulevard (Bodur, 1990, 203-221) (Figure 3).

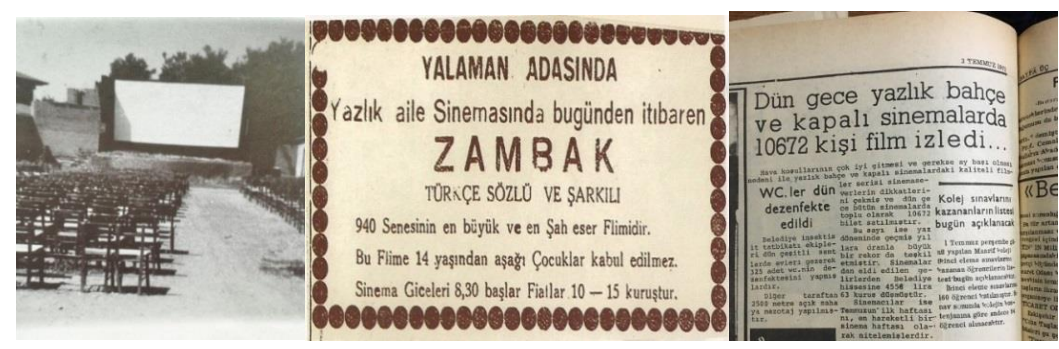

The movie "Lily" with Turkish language and songs is the best movie of the year 1940, and it will be screened in the Family Summer Theater in Yalaman Island. Children under 14 will not be accepted. Movie starts at 8.30 p.m. Tickets cost 10-15 cents.

Last evening, 10672 persons watched movies in garden theaters and other movie theaters. Besides the ones on Porsuk Boulevard, many garden movie theaters were opened in many districts in Eskisehir, however they did not last long. These were Zafer Garden in Zafer District, Osmangazi Garden in Osmangazi District (established by İsmail Aydoğan, and active from 1965 to 1970),
Figure 3. Renk Bahçe Movie Theater (Atuk's archive), Eskisehir Yeni Newspaper, 1940, July 3rd, 1971, Sakarya Newspaper (Yastıkçı's archive). 
and Seylap Garden in Seylap District (by Osman Düzenli, from 1952 to 1964). One summer theater in Tepebaşı and another in Yıldıztepe districts were run for a short time (Bodur, 1990: 203221).

After television sets found their place in homes, garden cinemas ceased to be the socializing spots. A number of nostalgic screenings attempted to sustain the culture in recent years.

\section{Independent Movie Theaters}

The history of independent movie theaters in Eskisehir also dates back to that of garden movie theaters. The citizens' first encounter with cinema was in 1926, when silent movies were screened in the first movie theaters. Especially from 1935 to 1950 , the number of movie theaters in the city increased dramatically. From 1926 to 2008, 16 movie theaters were active in the city and most of them were located in the city center.

This data is the updated information of Feyyaz Bodur's research in 1990. It was not easy to locate where the movie theaters were, since most of them did not remain in the memories of the citizens, but the information was updated by consulting the residents living nearby the spots. Information about these independent movie theaters, including their locations, their old and new photographs will be given below (Figure 4.).

Figure 4. Number and locations movie theaters in Eskisehir from 1925 to 2008 (Reinterpreted on Google Earth by Üstün, B., 2018)

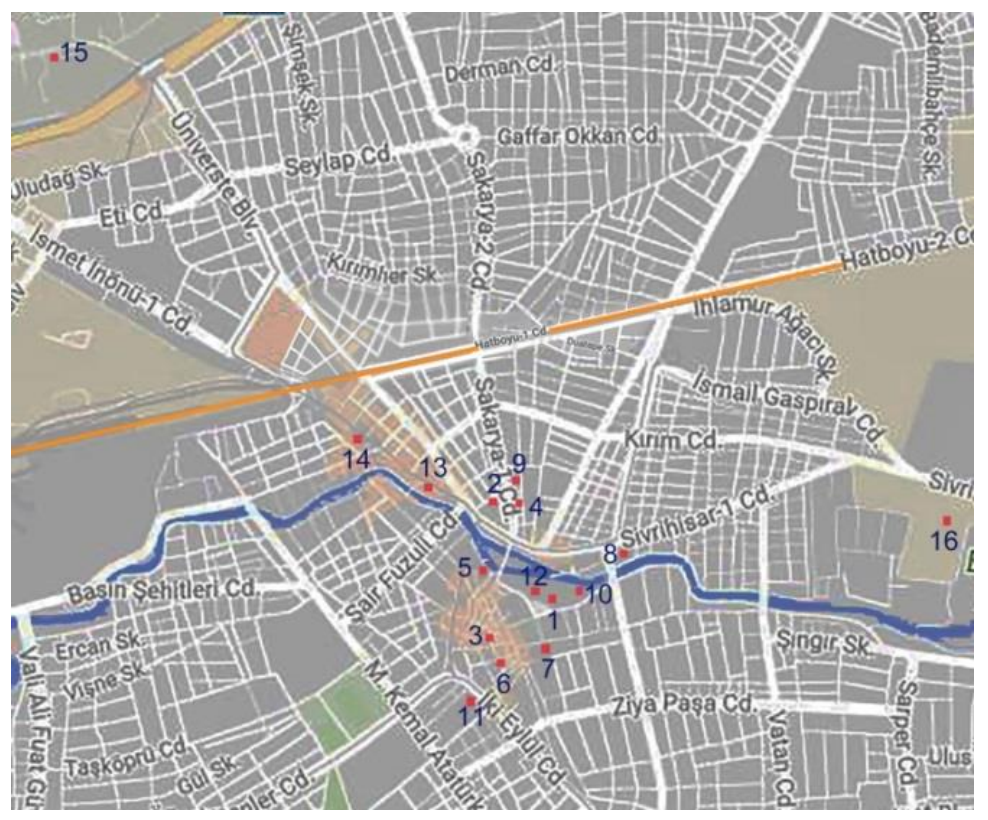

1. Park-Lale Movie Theater (1926-1943-unknow)

2. Asri Movie Theater (1928-2009)

3. Ethem Movie Theater (1930-1940)

4. Sizin Movie Theater (1936-1979) 
5. Yeni Movie Theater (1936-1990s)

6. SŞentürk Movie Theater (1940-1941)

7. Marmara Movie Theater (1940-1979)

8. Şan Movie Theater (1951-1987)

9. Atlas Movie Theater (1952-1987)

10. Yurt Movie Theater (1954-1975)

11. Büyük Movie Theater (1955-1978)

12. Doğan Movie Theater (1957-1990s)

13. Kılıçoğlu Movie Theater (1959-2008)

14. Arı Movie Theater (1973-2000)

15. Cinema Anadolu Movie Theater (1975-today)

16. Sugar Factory Movie Theater (1950)

Park Movie Theater - Lale Movie Theater (1926-1943unknow):

Park Movie Theater was established by Ethem Berksoy and Hasan Tozman in 1926, and it used to screen silent and short films. After it was closed, Hasan Tozman opened Lale Movie Theater in 1943 at the same place (Sıcaksular, Değirmen Street) (Bodur, F., 1990: 203-221). This region of the city was a marketplace with Turkish baths and shops. Its proximity to Köprübaşı, which can be called the city center, made the neighborhood a frequently used place in the daily life of urban dwellers. Lale Movie Theater used to screen good foreign movies, and the entrance was a long corridor from the street to the cinema hall. The hall included first-class seats, private seats and regular seats (Uluvar, B., 2006 - URL1). Today, the corridor in the entrance of the cinema does not exist, and the saloon is used as a wedding hall (Table 1). 
Table 1. Park Movie Theater - Lale Movie Theater

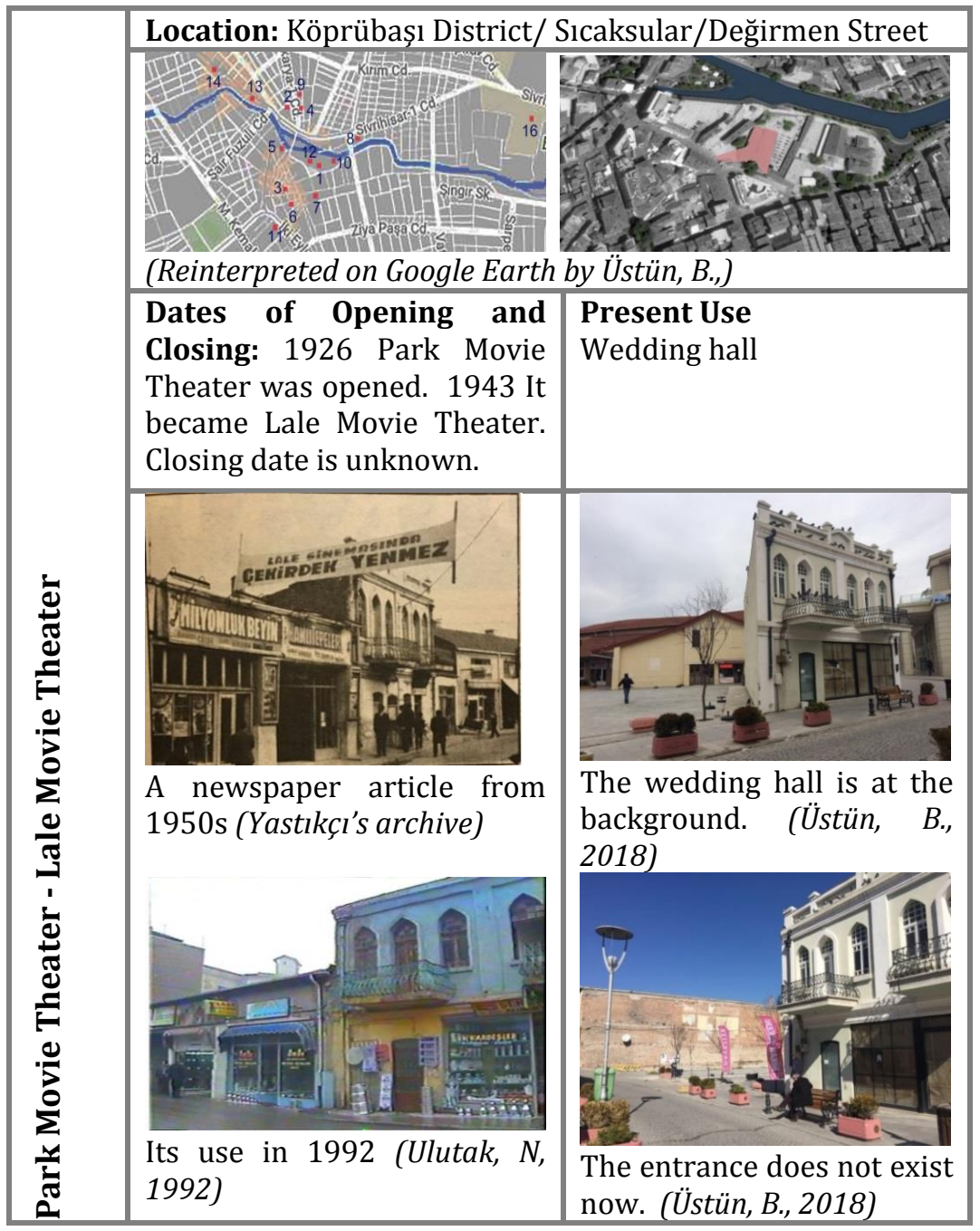

\section{Asri [Modern] Movie Theater (1928-2009):}

The building of Surp Yerrortutyun Church or Holy Trinity Armenian Church is located in Hoşnudiye District, which used to be an Armenian neighborhood. Armenian habitants in Eskisehir were forced to emigrate, and who remained were expelled in 1922, during the population exchange with Greece. As the church was desolated after this date (URL-2), in 1928, Hasan Tozman and Hikmet Özbil rented the building, which then was owned by state foundations and established Asri Movie Theater (Bodur, F., 1990: 203-221). It was rented from National Estate, and managed by Ethem Berksoy in 1931, by Hasan Tozman from 1932 to July 1937 and by İbrahim Çanakçı from August 1937 on. In July 1948, the building took fire, and stayed under restoration (note 3) (Arda, E., 2005: 35).

Then, the building was sold, and started working again (URL-3), managed by Hikmet Tozman in 1950, by Cahit Tozman and Kamil Tozman in 1975. While its capacity was 40 in 1965, it increased to 
An Anatolian City: A Research on Cinema Culture and Movie Theaters in Eskişehir

600 in 1990s. It was considered to be one of the luxury movie theaters in Eskisehir. It had massive audience until mid-1970s, with a mini movie theater for children which did not last long due to low demand. From 1974 on, adult movies were screened in the cinema (Bodur, F., 1990: 203-221). It was restored once again in 2009 and today it is used as Zübeyde Hanım Culture Center (URL2 ). It is one-volume with a central dome. Its structure with an axis of abscissa towards east can be seen inside. Architectural unity was destructed by an addition of a balcony (URL-4). (Table 2).

Table 2. Asri Movie Theater

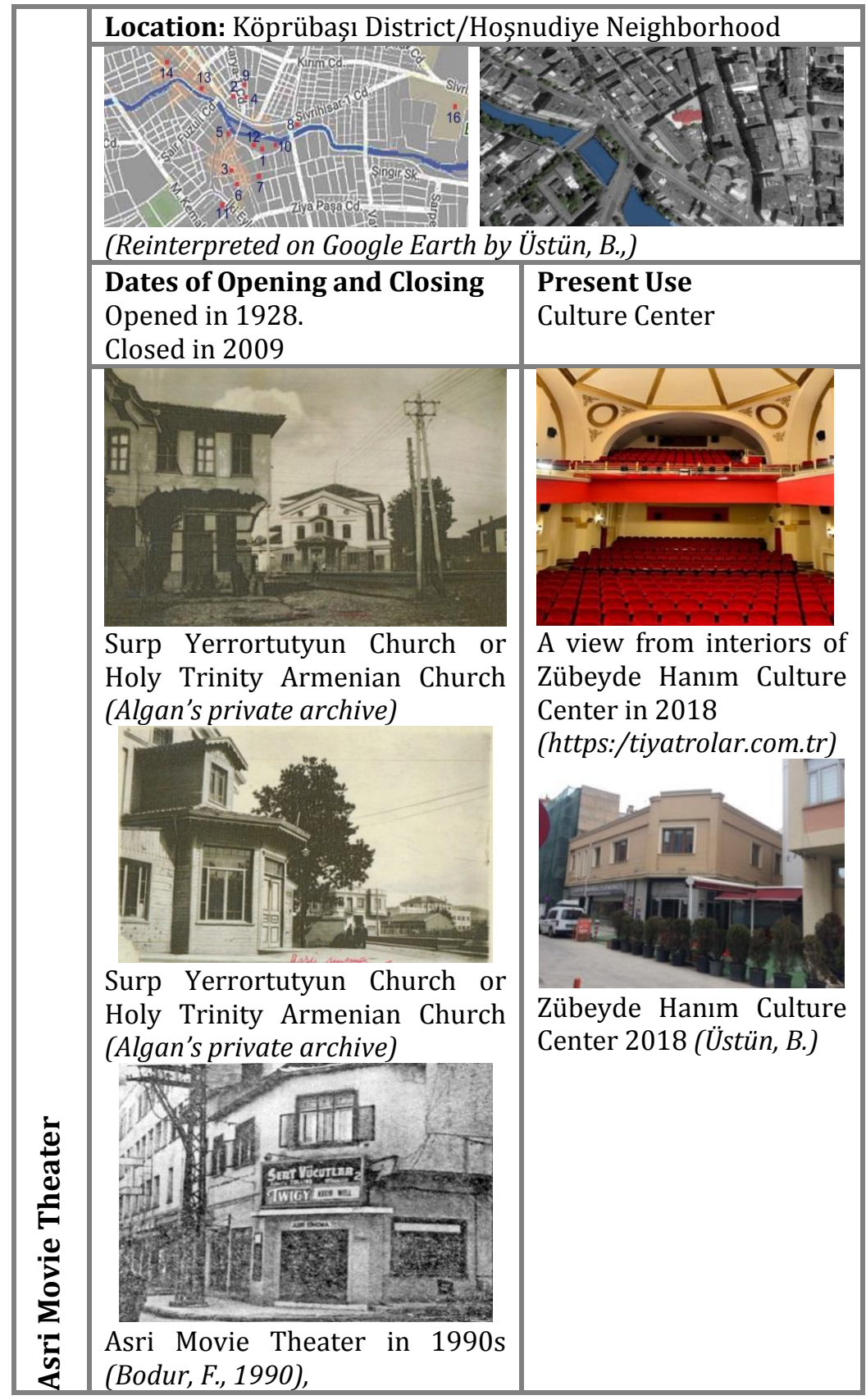




\section{Ethem Movie Theater (1930-1940):}

Ethem Berksoy established the movie theater in Hamamyolu Road, Taşbaşı-Banka Street in 1930. It became very popular soon as it was located in a very frequently used axis in the city, which connects the region of the first settlement with a traditional urban texture, Odunpazarı with Köprübaşı the city center with Turkish baths, shops, market places, etc. After it was closed in 1940, the building was used as shops (Bodur, F., 1990: 203-221) (Table 3).

Table 3. Ethem Movie Theater

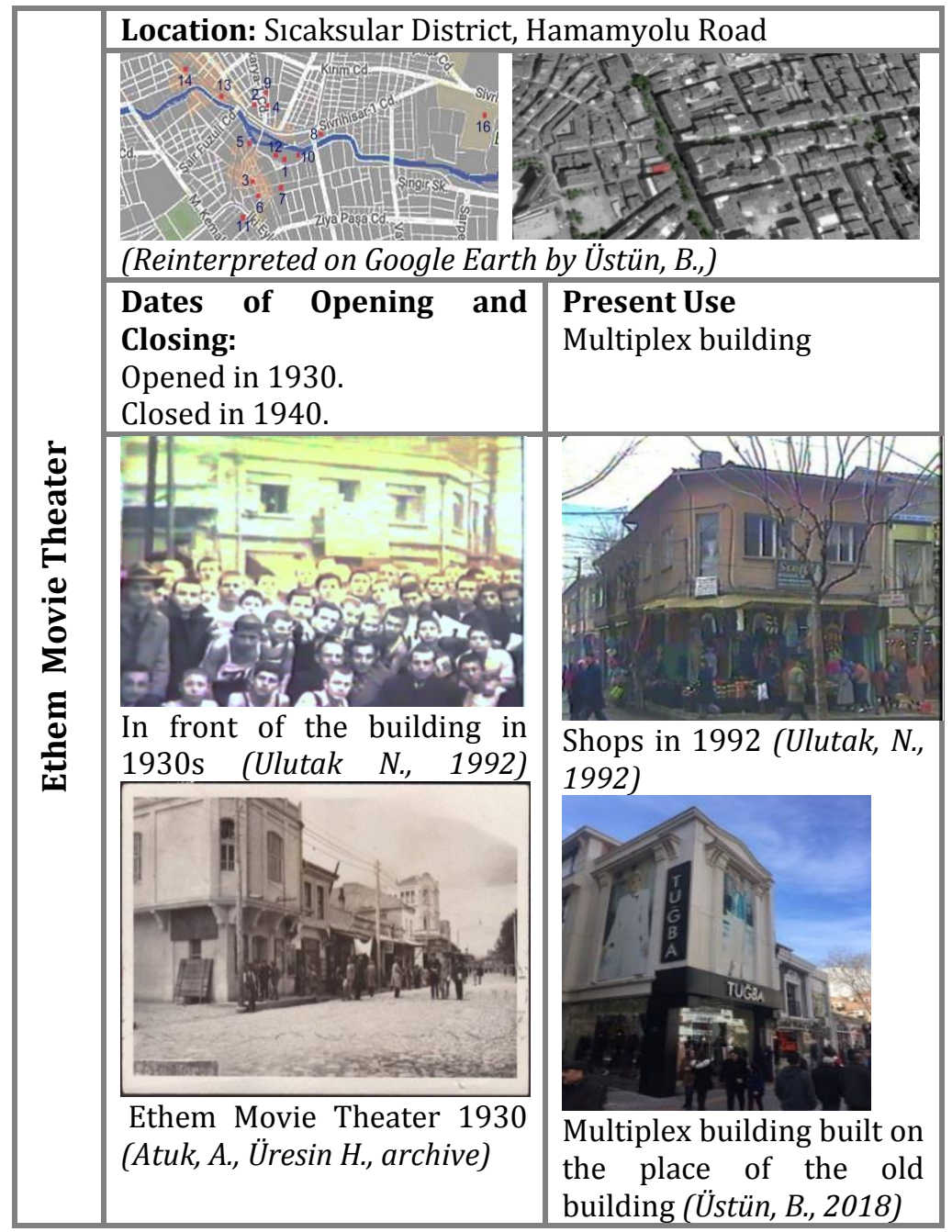

\section{Sizin Movie Theater (1936-1979):}

Wine Producer Muharrem Rıfkı Gösteren established the movie theater on Sakarya Road, at the entrance of Bayat Market place in Köprübaşı District in 1936. Silent movies were screened in the movie theater at the beginning (Feyyaz, B., 1990: 203-221). It was the smallest and the cheapest movie theater with two balconies. The ground floor consisted of cheap wooden seats. The seats on the upper balcony were made of leather. The other balcony was furnished with wide and comfortable luxury armchairs (Uluvar, B., 2006 - URL1). Peyami Kanışkan rented the cinema in 1967. In 
An Anatolian City: A Research on Cinema Culture and Movie Theaters in Eskişehir

1979, the building was demolished, and an apartment building was built on its lot (Bodur, F., 1990: 203-221). (Table 4)

Table 4. Sizin Movie Theater

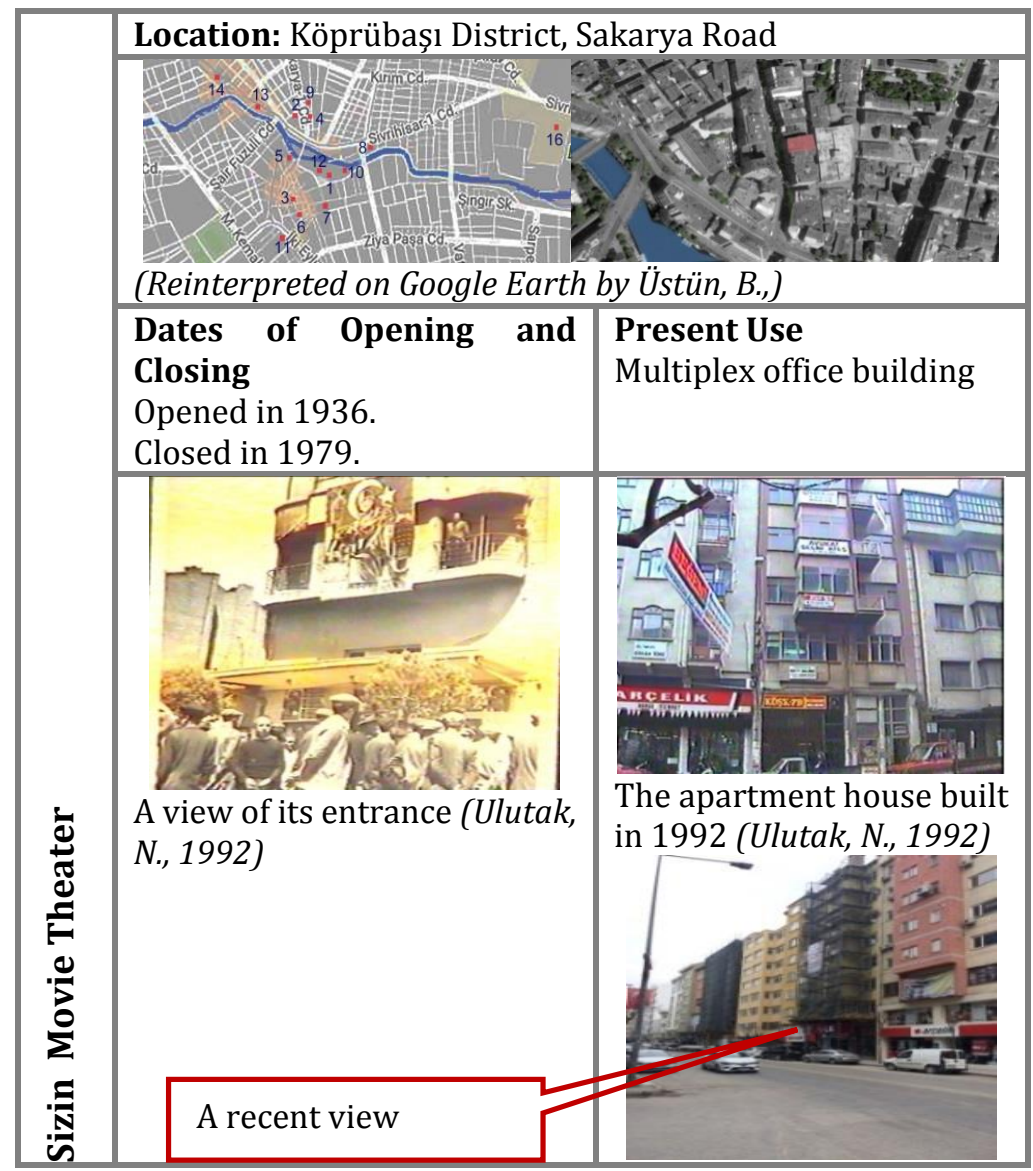

\section{Yeni Movie Theater (1936-1990s):}

Hasan Tozman established Yeni Movie Theater on Porsuk Boulevard in 1936. The upper floors of the building were used as a hotel. It was managed by Çetin Tozman, Hikmet Tozman, Ethem Arda (in 1977) and Mustafa Öztürk. The saloon was also used for theater and music performances besides screenings. Its capacity was 650 seats, 250 being on the balcony. The first color film was screened in Yeni Movie Theater in 1940 (Bodur, F., 1990: 203-22). (Table 5). 
Table 5. Yeni Movie Theater

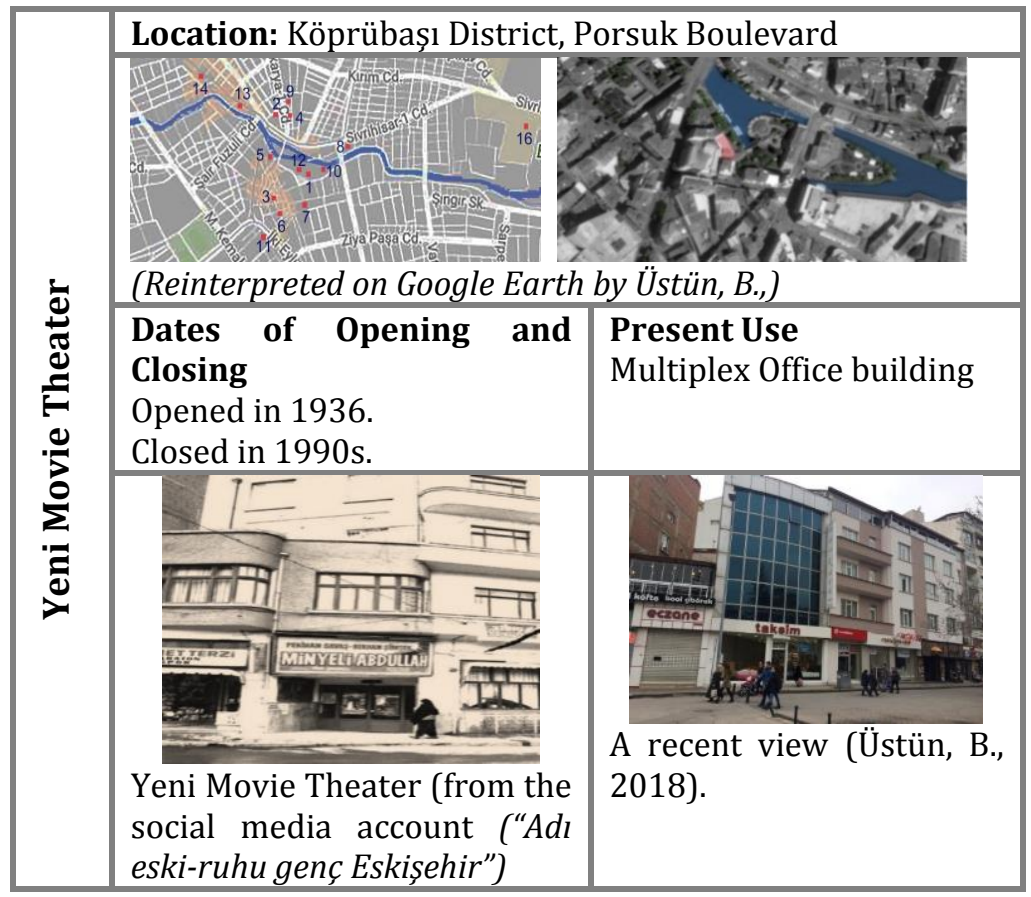

\section{Şentürk Movie Theater (1940-1941)}

Hasan Avar opened Şentürk Movie Theater in 1940 on Kıbrıs Şehitleri Road near Hamamyolu Road. It was used for theater performances in the evenings, and movie screenings during daytime. It lasted only 6-7 months. Today, Sipahi Office Building occupies its lot (Bodur, F., 1990: 203-221) (Table 6).

Table 6. Şentürk Movie Theater

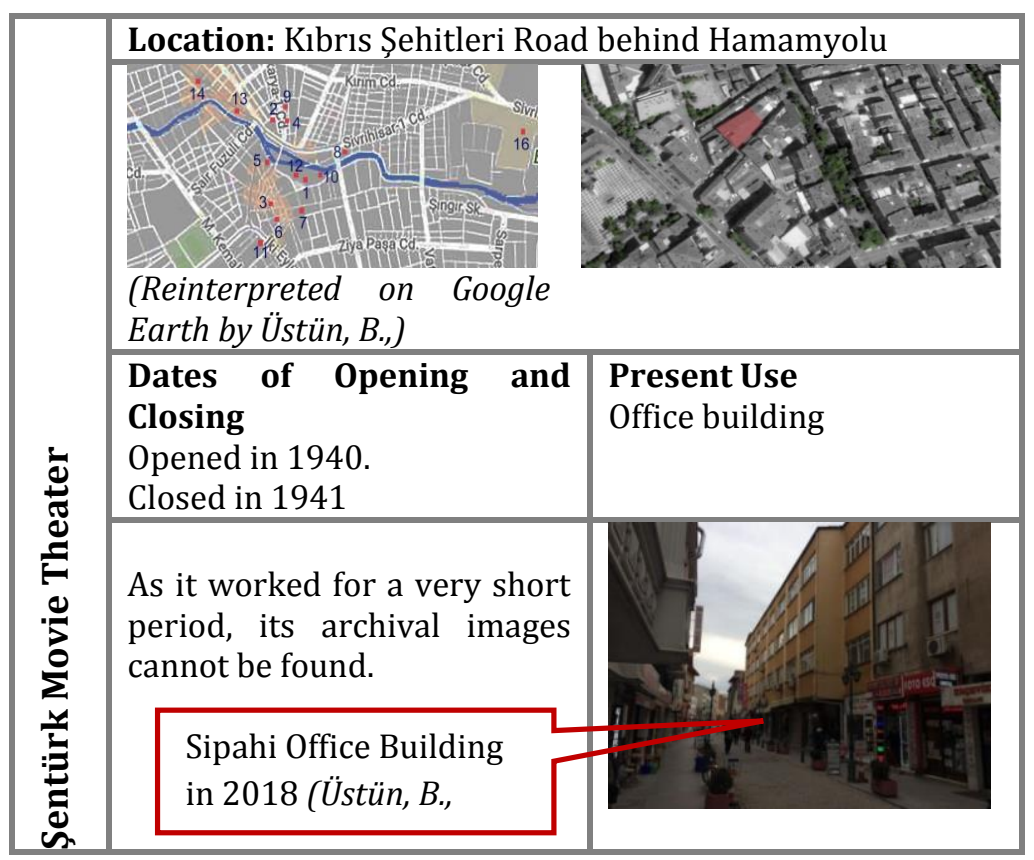




\section{Marmara Movie Theater (1940-1979):}

After Ethem Movie Theater was closed, son of its manager Ethem Berksoy, Dr. Süleyman Berksoy opened Marmara Movie Theater very close to his father's movie theater on Asarcıklı Road. It was a popular cinema due to its location: Hamamyolu tradesmen and Odunpazarı families frequented the place. After 40 years of mostly Turkish movie screenings, it was closed in 1979 (Bodur, F., 1990: 203-221). Prof. Dr. Nazmi Ulutak interviewed its projectionist İlyas Cankılıç for his research in 1992. Cankılıç claims that the first female projectionist of Turkey worked in Marmara Movie Theater (Table 7).

Table 7. Marmara Movie Theater

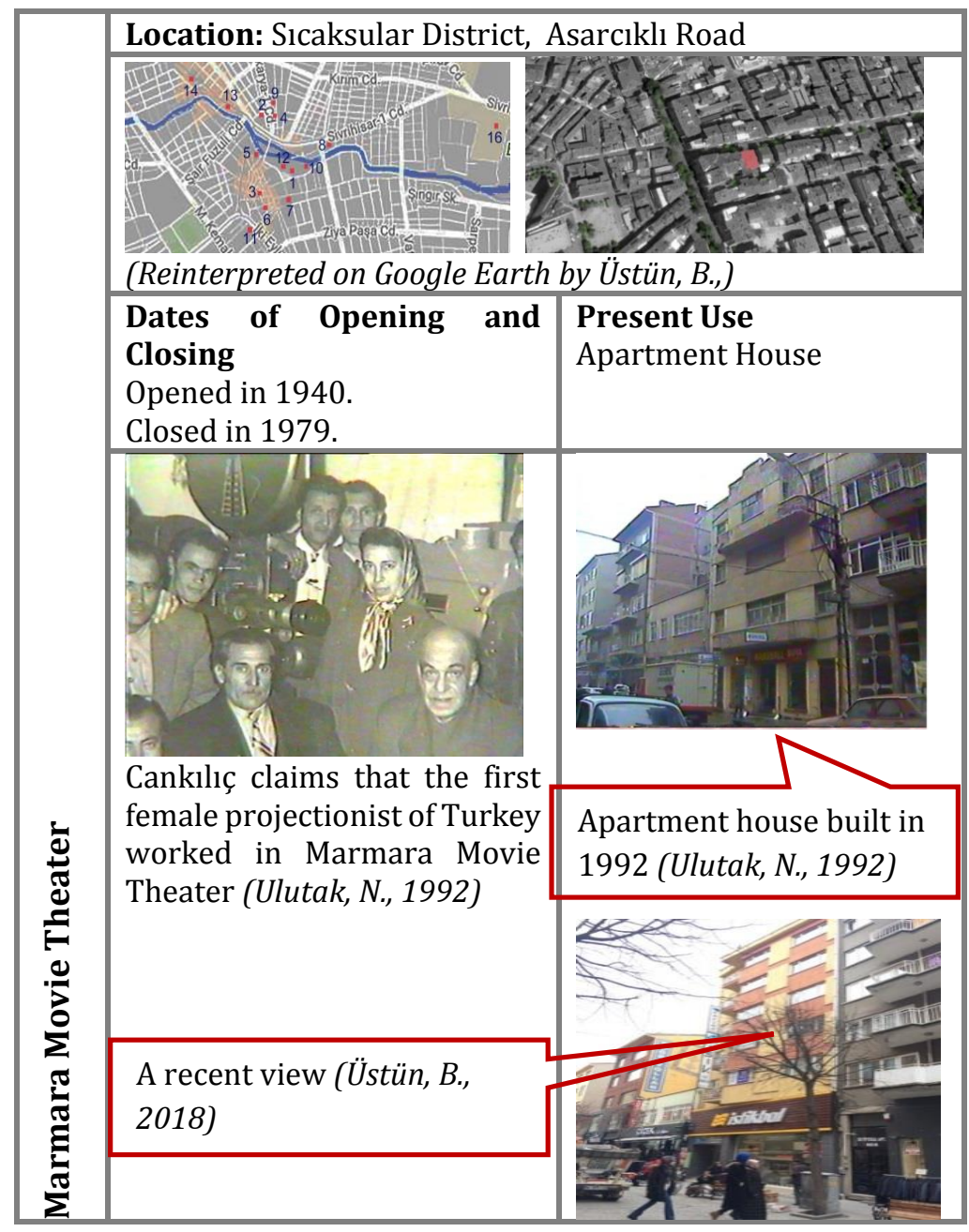

Altay - Halkın - Şan and İkizler Movie Theaters (1951-1987): Dr. İsmail Altay established it in 1951 as Altay Movie Theater on Sivrihisar Road. Fuat Rutkay, the manager of Halk Film run it under the name of Halkın Movie Theater, and Baki Üsküdarlı of Şan Movie Theater in Istanbul and Ethem Arda run it as Şan Movie Theater. Finally İsmail Aydoğan run it as İkizler Movie Theater 
Figure 5. March $27^{\text {th }}, 1973$, Șehir Newspaper (Yastıkçı's archive) until 1987. The building was demolished and became a car park (Bodur, F., 1990: 203-221).(Figure 5) (Table 8).

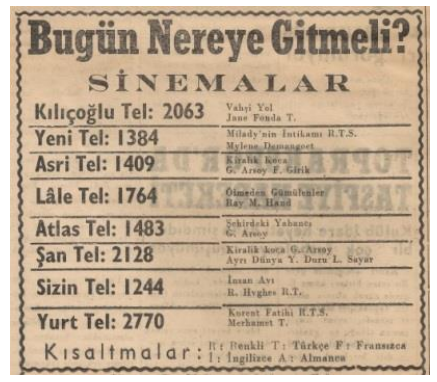

Table 8. Halkın-Şan-İkizler Movie Theater

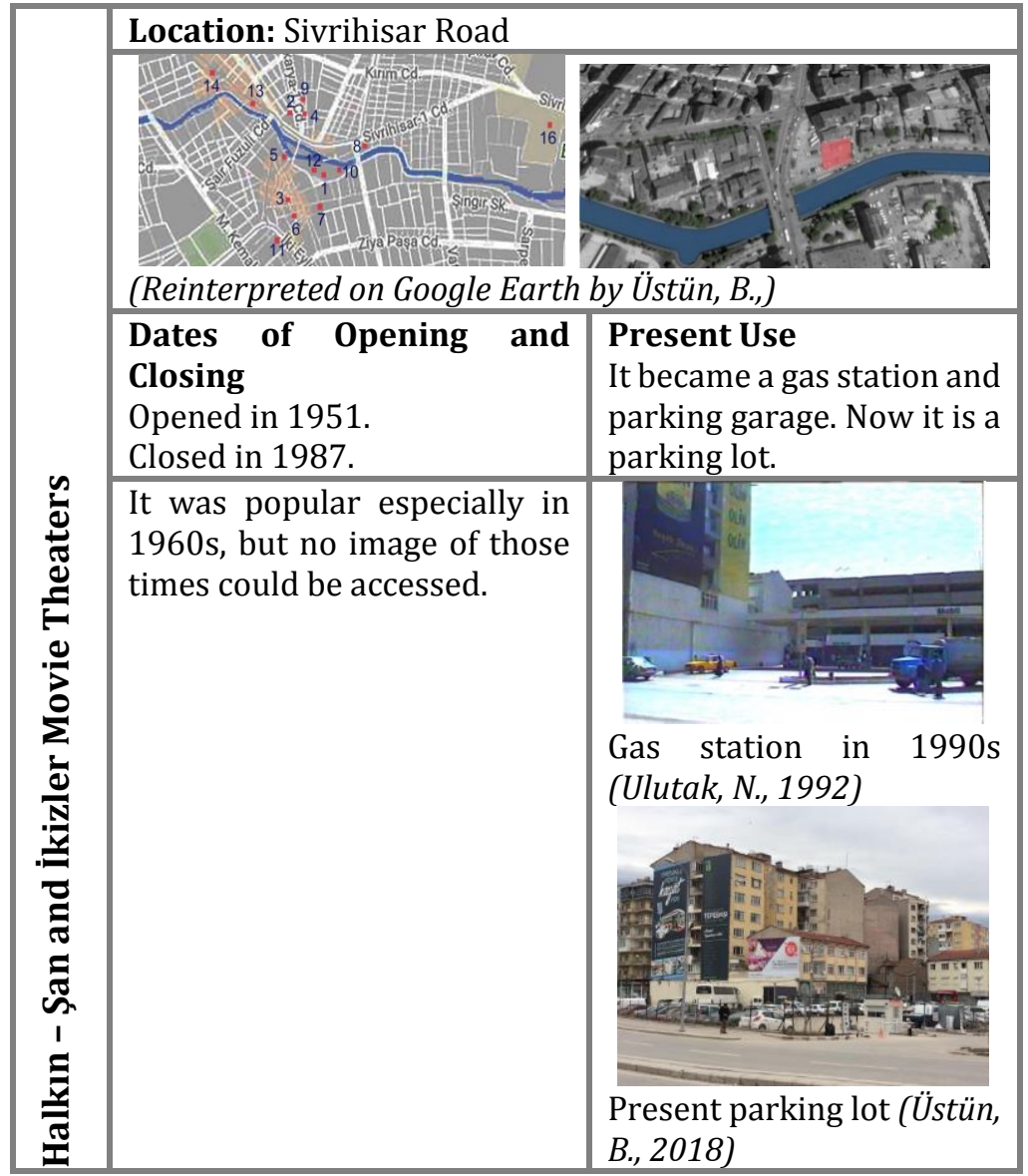

\section{Atlas Movie Theater (1952-1987):}

Atlas Movie Theater was opened on Sakarya Road in 1952 by İbrahim Çanakçı. Until 1958, it was known as Eski Atlas (Old Atlas), and in 1959 it was restored to be run as Atlas. It was run by Şükrü Pişiren from 1962 to 1967, by İsmet Bey from 1967 to 1968, and İsmail Aydoğan from 1968 to 1969. It remained inactive for years, and after a short period of screening again, it was finally closed in 1987 (Bodur, F., 1990: 203-221). (Table 9). 
Table 9. Atlas Movie Theater

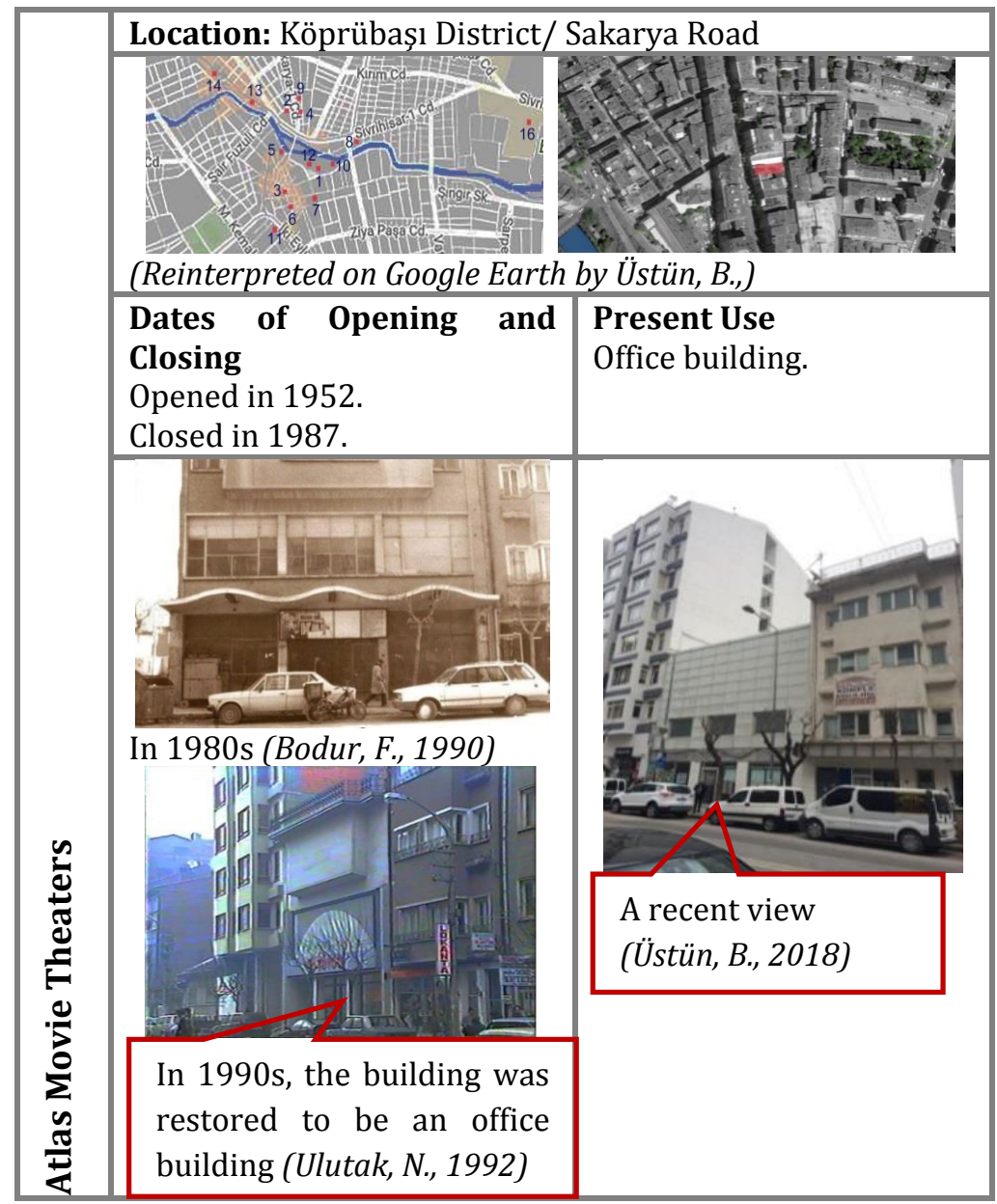

\section{Yurt Movie Theater (1954-1975):}

Ahmet Atuk claims that Yurt Movie Theater was built in 1954 on the lot where Greek Orthodox Church once was, while Prof. Dr. Ertuğrul Algan asserts that it was Saint Croix French College (Atuk, A., 2002: 110; interview with Prof. Dr. Ertuğrul Algan in February 2018) (Image 12). After the Greek burned and left the city, the church remained in ruins until 1950s. Emin Sazak bought the building from the National Estate (Arda, E., 2005: 49). Bican Toker, Sazak's son in law hired Muharrem Zeytinoğlu to design the new building. The movie theater was on İki Eylül Road, by which summer movie theater Yurt Bahçe Garden Cinema also was run. In 1975, the building was demolished and office and apartment buildings were built in the same lot. Yurt Movie Theater used to have two lounges, one at the entrance and one on the first floor. It was the most comfortable movie theater of its period (Uluvar, B., 2006, URL-1, Bodur, F., 1990). (Table 10) 
Table 10. Yurt Movie Theater

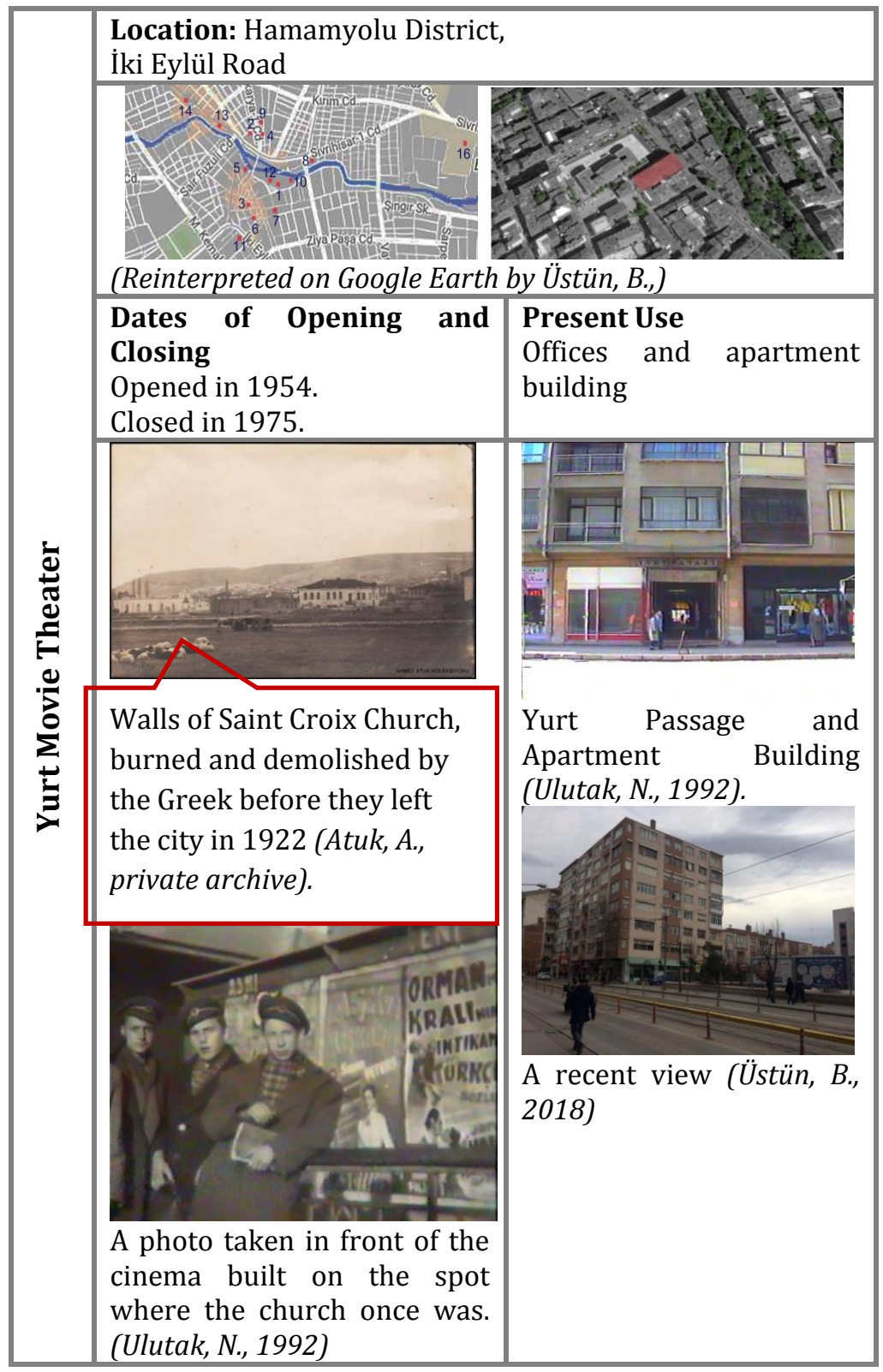

\section{Büyük (Grand) Movie Theater (1955-1978)}

It was opened on the small peninsula where Akarbaşı Stream met Porsuk River in 1955. The garden was accessed by a bridge. It was the largest movie theater in 1950s. Although it did not have a balcony, there were two lodges at the back of the hall and on the second floor. It often screened Turkish movies, and it also had a summer garden by the hall. After the cinema was closed in 1978, it was used as a market, and now it functions as a store. The interiors have changed dramatically (Uluvar, B., 2006 ,URL-1, Bodur, F., 1990). (Table 11) 
Table 11. Büyük Movie Theater

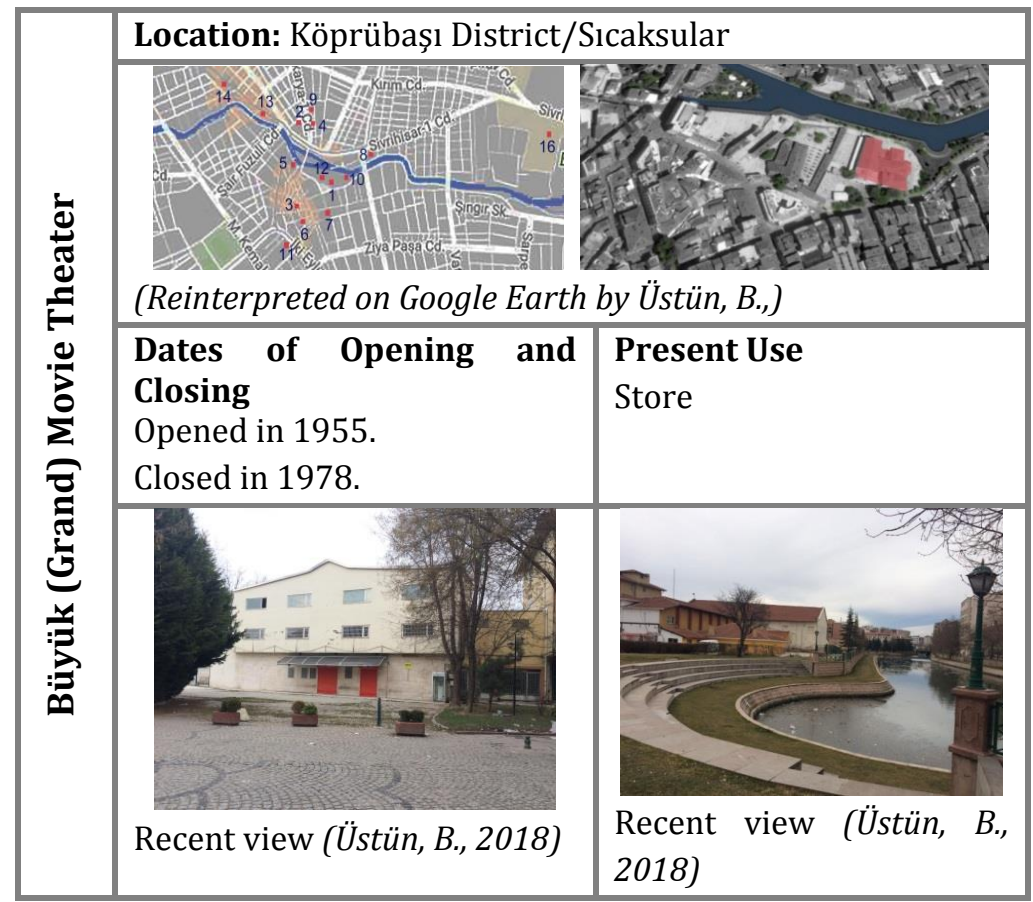

\section{Doğan Movie Theater (1957-1990s):}

Doğan Movie Theater was on a dead end so close to Lale Movie Theater, a passage connecting them (Uluvar, B., 2006, URL-1). It was opened by İsmail Aydoğan in 1957, and run by Rahmi Kanışkan from 1968, and by Aydoğanlar family from 1970 on. In 1963 , it was restored. After 1975, the erotic movie rush made it a very popular movie theater, with seven-eight thousand audiences perweek (Bodur, F., 1990: 203-221). It was closed, and the building was demolished in 1990s. (Table 12) 
Table 12. Doğan Movie Theater

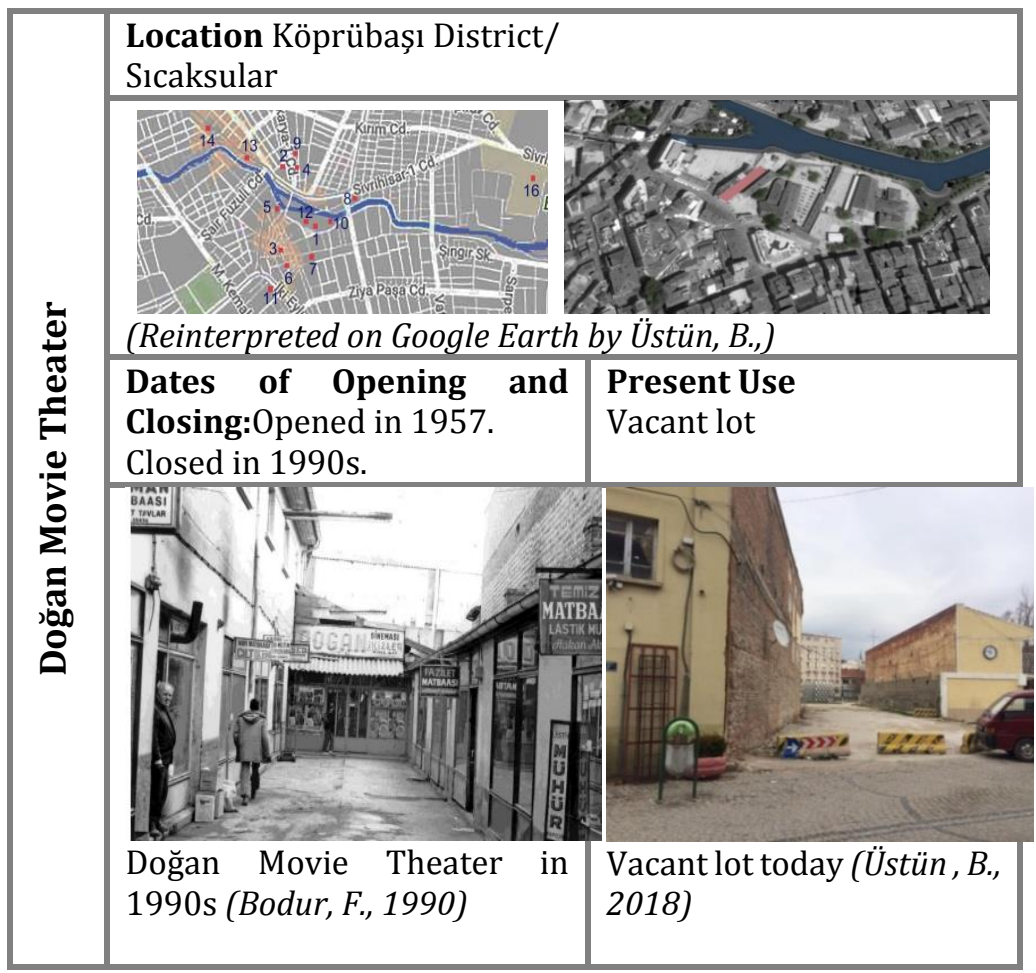

\section{Kılıçoğlu Movie Theater (1959-2008):}

Abidin Mortaş, the architect designed the building, and the cinema was opened in 1959. (note 4). The building was designed as an attached plan on the large plot, its front façade facing İsmet İnönü (Doktorlar) Road, and rear facade facing Porsuk River. It used to function as movie theater, office building and apartment building. The movie theater was below the office building part, on the side of Porsuk River. On the ground floor, below the apartment part, there used to be a passage which connected the road with the riverside, and functioned as an entrance to both the offices and the cinema (Karasözen, Rana \& Koca, Güler, 2010: 200). It was run by Ethem Arda, one of the most experienced cinema managers of Eskisehir. It was the most innovative cinema of Eskisehir, in terms of the technical equipments, and the movies screened. It also functioned as a theater stage and a concert hall. After years it had one large hall, it was divide into three small saloons, as the number of audiences decreased in time (Tutal, O., URL-5).

Kılıçoğlu Movie Theater transcended a regular movie theater: It used to be the meeting point for the citizens. Campaign were organized to stop its destruction, but the cinema was closed in 2008, and evacuated in 2009. Today, Yalçın Kılıçoğlu Plaza is in the process of construction at the plot. (Table 13) 
Table 13. Kılıçoğlu Movie Theater

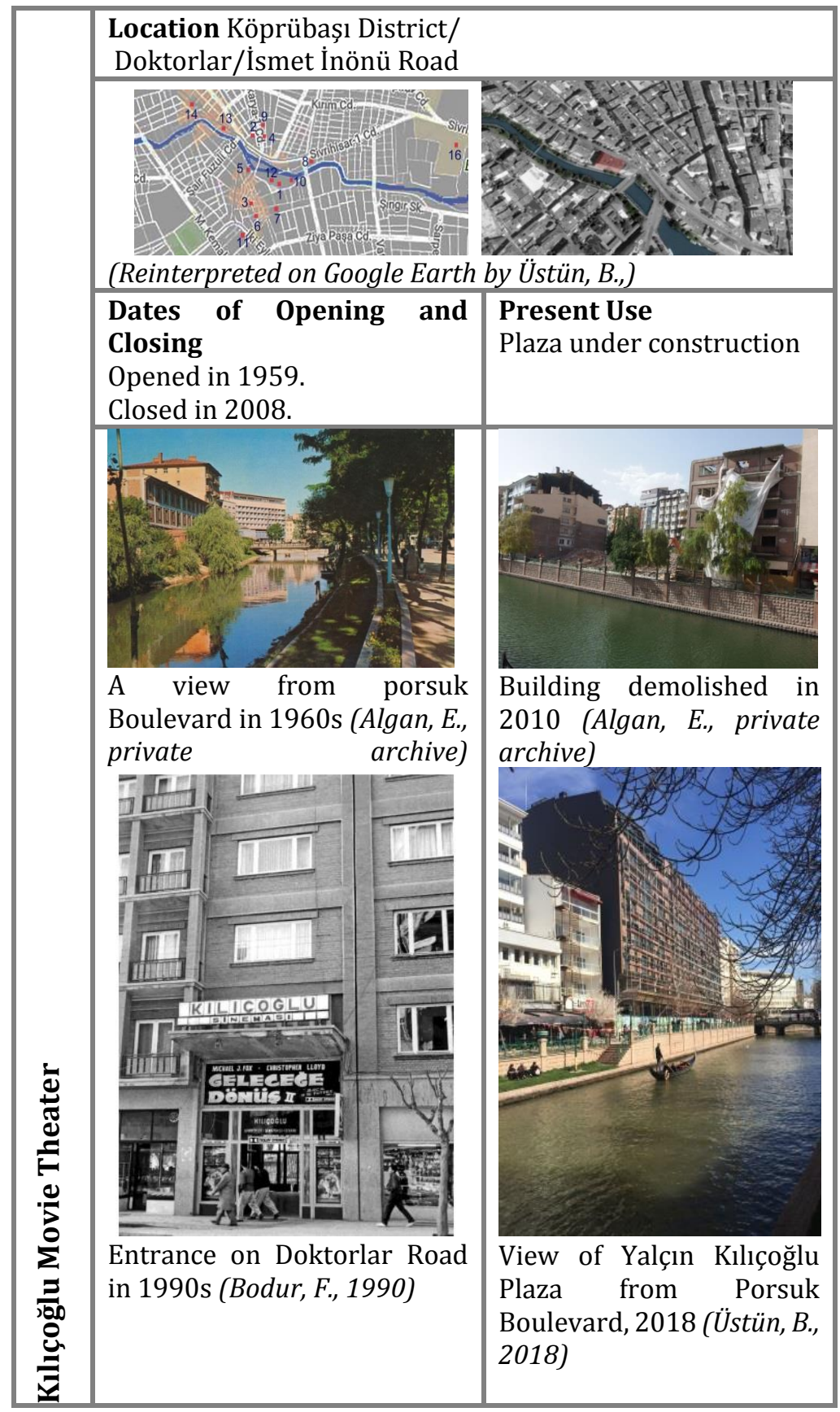

\section{Arı Movie Theater (1973-2000s):}

It was opened by Şenol Özgür on İstasyon Road in 1973. It was run by Mustafa Öztürk and Ali Akyüz from 1976 on, by Ali Akyüz and Hasan Ekici from 1981 on, and Rıza Karataş from 1989 on. The cinema with a capacity of 1100 seats was also used for theater plays and concerts (Bodur, F., 1990: 203-221). The movie theater which was located on the basement and ground floors of an apartment building was closed in 2000s. (Table 14) 
Table 14. Arı Movie Theater

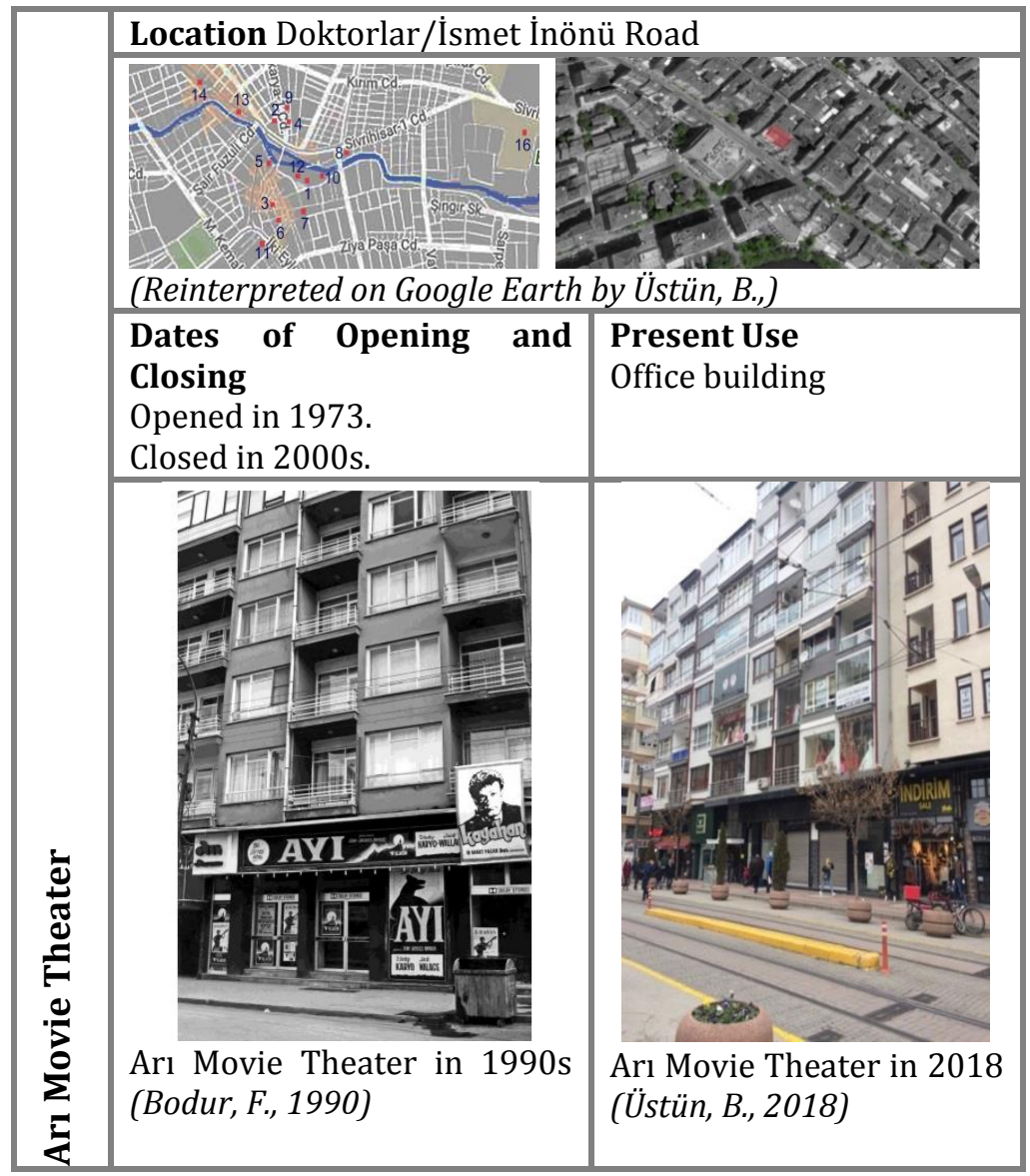

Besides the fourteen independent examples mentioned above, many public institutions built movie theatres in their campuses. One movie theater is known to exist in Turkish Railways facilities, and another in Central Command Headquarters once used as Officer's Club, in the military lodgements. Two of the movie theaters, as mentioned in the introduction of the present study, played a significant role in the socio-cultural life of the city: Cinema Anadolu in Anadolu University, and Movie Theater in Eskisehir Sugar Factory Campus.

\section{Cinema Anadolu (1975-today):}

Cinema Anadolu was opened in Yunusemre Campus in 1975. It has a capacity of 400 seats, and it frequented not only by university students but also urban dwellers. The hall functions as theater stage, concert hall and meeting hall (Bodur, F., 1990: 203221) (Table 15). Throughout its active use since the day it was opened, Cinema Anadolu also hosts the film festival of the university, and attracts citizens of Eskisehir. 
Table 15. Cinema Anadolu

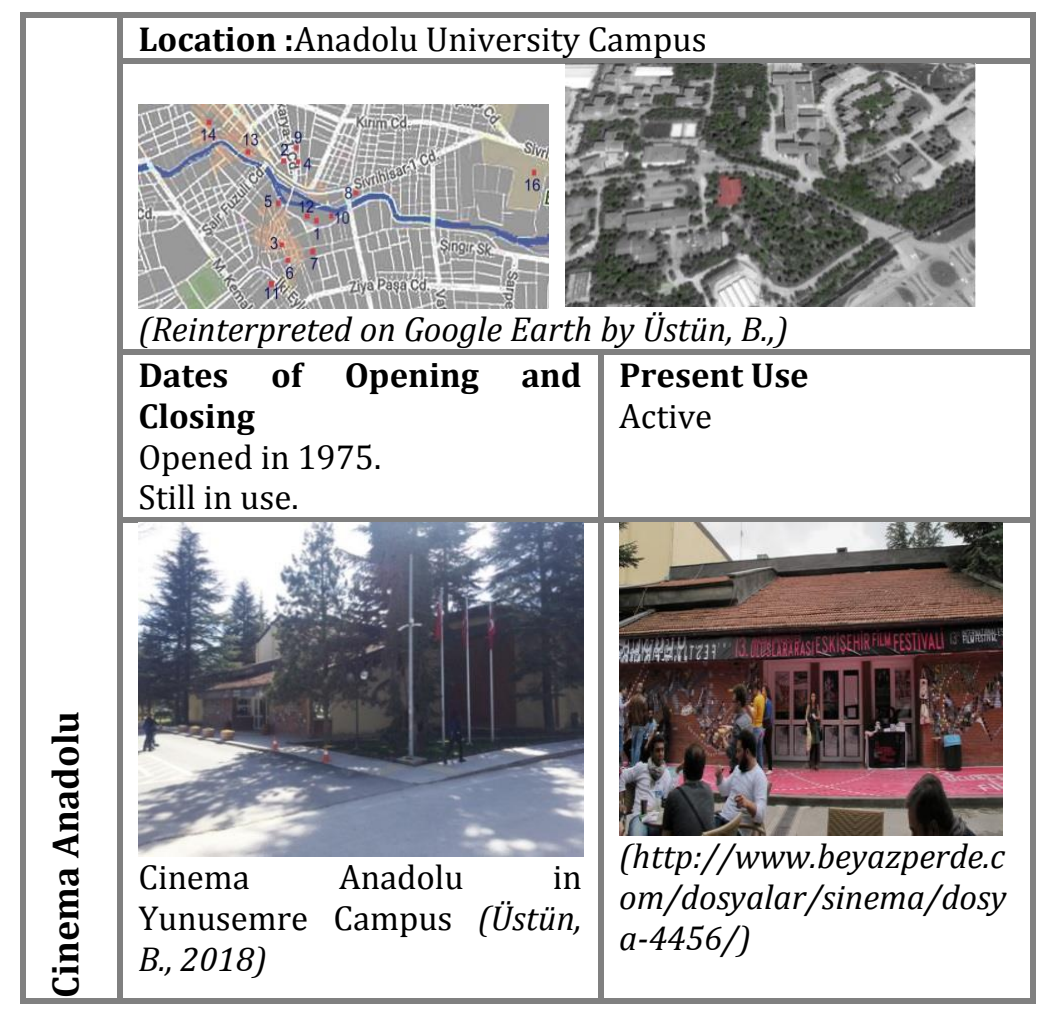

\section{Eskisehir Sugar Factory Movie Theater (1950-today functions as cafeteria):}

The movie theater building in the social facilities in Sugar Factory Campus remains today without major alterations. In 1950s, it used to screen movies once a week for the officers, and once a week for their children, on Sundays (Arda, E., 2005: 51) (Table 16). It is an important place, as it served as a theater stage to all the citizens in a period when all theaters were closed in the city. The acoustics and lighting details were designed by German engineers, and the building has a balcony on the upper floor. The hall and the balcony now functions as the cafeteria of the guesthouse. The stage and the silver screen is protected. 
Table 16. Eskisehir Sugar Factory Movie Theater

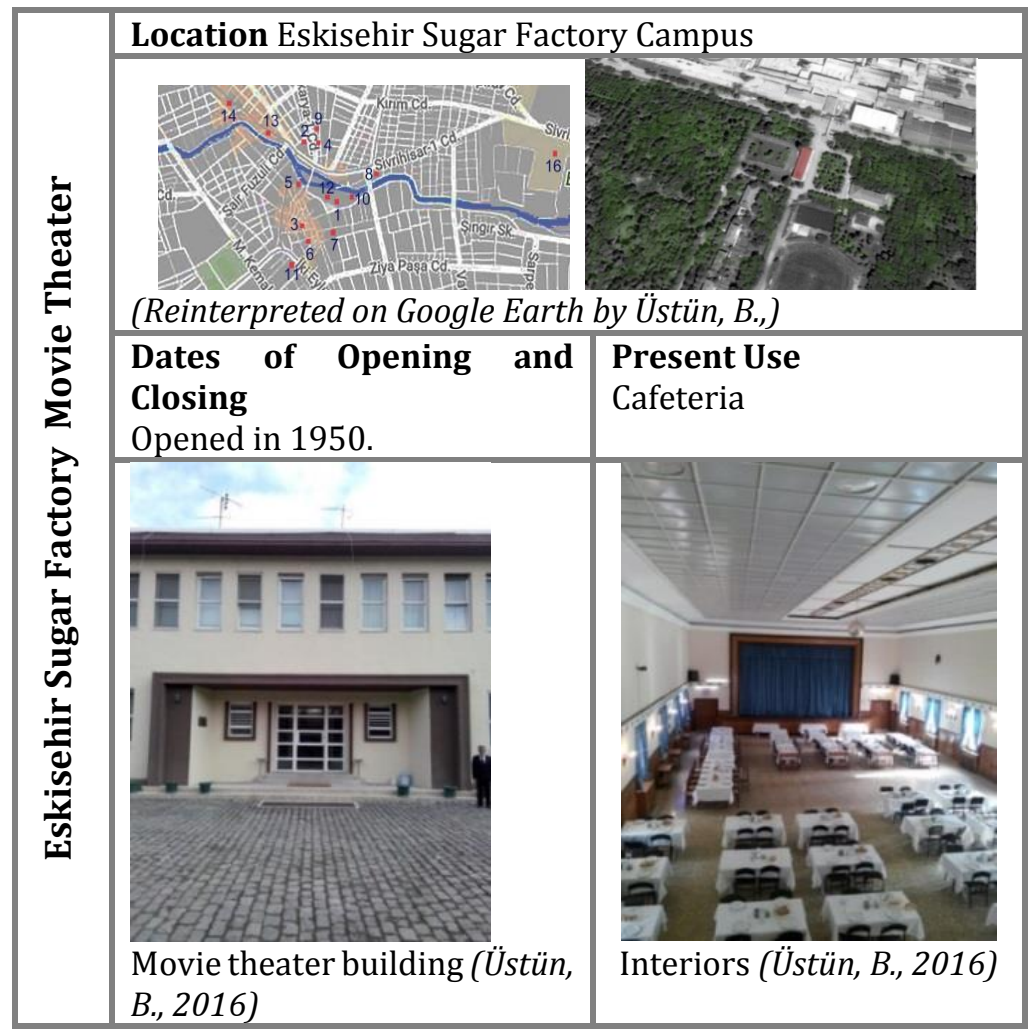

\section{CONCLUSION AND EVALUATION}

The table 17. demonstrates the active years of the movie theaters in Eskisehir. The first movie theaters were opened in the republican period, and many new ones followed in 1935 and 1950s. As these buildings functioned as theater and concert halls, they played a significant role on the cultural life of Eskisehir. 1970s came with the advent of technologies such as television and video, which altered the cultural habits dramatically. While families used to dress up and gather together to meet others and socialize in movie theaters before, cinema culture became an individual indoors activity. 
An Anatolian City: A Research on Cinema Culture and Movie Theaters in Eskişehir

Table 17. The active years of the movie theaters in Eskisehir.
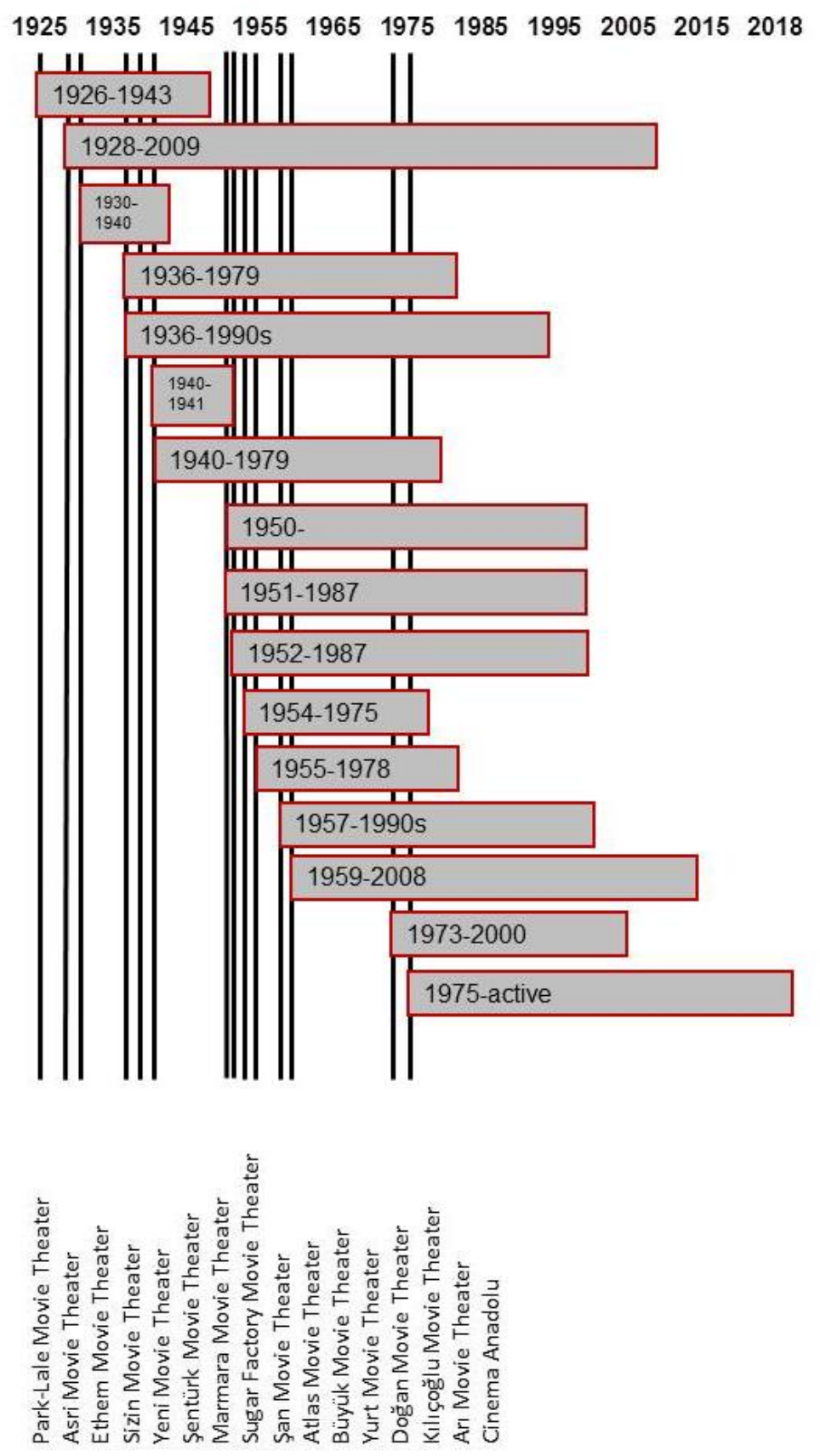

This transformation in media technologies, which allowed the activity of watching movies in other places than cinemas made socialization in cinemas extinct. The transformation of consumption habits and spaces also transformed the forms of cultural consumption. Movie theaters lost their functions, and got into a process of transformation with the impact of the capital. Independent movie theaters ceased to exist, and multi-saloon cinema complexes in the shopping malls appeared.

Global and local aspects of this transformation appeared in Eskisehir in fast phase, from 2007 on. As the first shopping mall, 
Kanatlı was opened in the city, Kılıçoğlu Movie Theater, which was the last surviving movie theater, closed in 2008. Now, the only movie theaters of the city are in Kanatll, Özdilek and Espark shopping malls.

Today, the only independent movie theater is Cinema Anadolu. As technology and consumption transformed, cinema spaces of the modernization process in the republican period lost their architectural variety, and became an object of consumption.

The present study attempts to record and document the transformation of movie theater buildings of the modern republican period in Eskisehir. It focuses on the spatial change in the city, which also alters the quality of urban everyday life.

\section{NOTES}

1. In a report to USA Ministry of Foreign Affairs in 1933 it is claimed that "most of the movie theaters are in big cities such as Istanbul, Ankara, Izmir, Adana, Bursa and Eskisehir; cities in Black Sea region, and in rich agricultural areas around Izmir" (as cited in Eugene M. Hinkle, Modern Türkiye'de Sinema, Kebikeç, 28/2009, 98). "The Motion Picture in Modern Turkey", A report to USA Ministry of Foreign Affairs dated August 1st, 1933 (Edited with an introduction by Rufat N. Bali, The Turkish Cinema in the Early Republican Years. Istanbul: The Isis Press, 2007)

2. Many garden movie theaters with various volumes were opened on Porsuk Boulevard until the year 1978. The River Porsuk and its surroundings have many names. Many citizens call it Yalaman's Island, Islands, Riverside, and etc. The spot is associated with entertainment and leisure. Now, there is no summer theaters left (Atuk, A., 2002: 122). Amusement parks were also built in the area in the past. Now, a hypermarket occupies the lot where summer theater and amusement park once was.

3. Ethem Arda writes the following on the fire in the building: "On July 2nd, I was working in Bahçe Movie Theater, and Remzi Kamış was in Asri Movie Theater. I went to Bahçe at 8 p.m., and started the evening screening at 9.15 p.m. I do not know when, a worker came running, and told me that the cinema was in fames. He was in a shock. I had nothing to do. It was not possible to cancel the screening in Bahçe, since it was stuffed with audiences. After the screening was over and I went to the building, I saw that it was horrible. The fire was extinguished by the fire service, the building was in smoke. The boss and the chief projectionist Yorgo were not there. They told me that Remzi the projectionist's body was burned, and 26 more were in the hospital. Remzi died in two days. The building was restored in two months (Arda, Ethem, 2005: 34). 
An Anatolian City: A Research on Cinema Culture and Movie Theaters in Eskişehir

4. Tutal claims that the architectural character of the building:

"............with its balconies on the apartment part, horizontal and vertical construction units, and the spatial impact of the fringe over the balconies, is very similar to other modern buildings, especially those designed by Abidin Mortaş, such as Nur Movie Theater and Hotel. Both building seem to use similar fringes, balconies, windows and doors of the balconies, however, the use of bricks produced by the client provides Kılıçoğlu building with a rich composition of materials, colors and textures" (Tutal, O., URL-5).

\section{REFERENCES}

Akçura, G. (2004), Aile Boyu Sinema, İstanbul:İthaki Yayınları Arda, E. (2005), Sinemanın Büyüsü, Eskişehir:Uğur Ofset Atuk, A. (2002), 1001 Eskişehir, Eskişehir:Onur Matbaacılık Baraz, T. (1988), Başlangıçtan Günümüze Eskişehir Basını (19801986), Anadolu Üniversitesi Açık Öğretim Fakültesi Yayınlarl, No: 134

Bodur, F. (1990), Eskişehir Sinemalarının Dünü Bugünü, Kurgu Anadolu Üniversitesi İletişim Bilimleri Fakültesi Uluslararası Hakemli İletişim Dergisi, Eskişehir, Sayı 8:203-221

Efe, A. (1998), Eskişehir Demiryolu, Anadolu University, Social Science Institute, Master Thesis, Eskișehir

Erkılıç, H. (2009), Düş Şatolarından Çoklu Salonlara Değişen Seyir Kültürü ve Sinema, Kebikeç Dergisi, Yll 14, Sayı 28:143162

Hauser, A. (1984), Sanatın Toplumsal Tarihi, çev: Yıldız Gölönü, İstanbul:Remzi Kitabevi.

Hinkle, E., (2009), Modern Türkiye'de Sinema, Kebikeç Dergisi, Yıl 14, Sayı:28:91-102

Jarvie, I. C. (1970), Towards a Sociology of the Cinema, Rutledge \& Kegan Paul.

Karasözen R. \&Koca, G. (2010), 1945-1960 Dönemi Eskişehir Modern Kent Merkezinin Oluşumunda Öne Çıkan Yapılar, Anadolu Ünv.Sosyal Bilimler Dergisi, Cilt 10, Sayı 3:191-211

Kırel, S. (2005). Yeşilçam Öykü Sineması. İstanbul: Babil Yayınları.

Kırlı, E. (2001), 19.ve 20.Yüzyılda Eskişehir'e Yapılan Göçler, Osmangazi University, Social Science Institute, Master Thesis, Eskişehir

Prof.Dr.Ertuğrul Algan ile görüşme yapılmıştır (Şubat 2018)

Sarıöz, P. (1997), Bir Zamanlar Eskişehir, Eskişehir:Esbank Yayınları

Ulutak, N. (1988), Belgesel Sinemanın Temel Özellikleri ve Tarih Felsefesi Açısından Belgesel Sinemada Gerçeklik, Anadolu 
University, Social Science Institute, Doctoral Thesis, Eskişehir

Yatağan, N. (2013), Cumhuriyet Dönemi Endüstri Yapıları ve Modernleşme İliş̧kileri Üzerine Bir İnceleme:Eskişehir Tülomsaş Yerleşkesi, Dokuz Eylül Ünversity, Institute of Science, Master Thesis, İzmir

URL-1 Uluvar, Behçet, 2006, Eskişehir'in Eski Sinemaları, (http://wowturkey.com/forum/viewtopic.php?t=3486 2), (Mayıs 2017)

URL-2 https://tr.wikipedia.org/wiki/Eskişehir_Surp_Yerrortut yun_Kilisesi (Eylül 2017)

URL-3 https://tr.wikipedia.org/wiki/Eskişehir_Surp_Yerrortut yun_Kilisesi (Eylül 2017)

URL-4 http://eskisehirkulturenvanteri.gov.tr/anitdetay.aspx?I $\mathrm{D}=165$ (Eylül 2017)

URL-5 Tutal, O., http://www.boyutpedia.com/1618/69322/kilic oglu-sinemasinin-gelecegi (Aralık 2017)

\section{Resume}

Berna Üstün works at Anadolu University, Department of Architecture, as a lecturer since 1989. She got her B. Sc and MSc degrees at Faculty of Architecture and Design at Anadolu University, Eskişehir, Turkey. She also obtained her PhD degree in Architecture and Design from Mimar Sinan Fine Arts University, İstanbul, Turkey. Her professions are traditional Turkish house, user participation in housing design and flexibility. She still lectures on architectural design. 